\title{
Por uma Fé Encarnada: teologia social e política no protestantismo brasileiro
}

\author{
Orientador: Joel Portella Amado \\ Doutorando: Wanderley Pereira da Rosa \\ Área de Concentração: Teologia Sistemático-Pastoral \\ Linha de Pesquisa: Religião e Modernidade
}

A pesquisa tem como propósito entender o ethos protestante: suas potencialidades, acertos e fracassos, especialmente em terras brasileiras. E, dentro desse universo, guarda uma questão específica referente ao papel social desse protestantismo. O cerne do estudo é simples e pode ser consubstanciado pela seguinte questão: o protestantismo brasileiro, em seu trajeto histórico no nosso país, deu alguma contribuição realmente relevante em termos sociais e políticos? A pergunta expressa curiosidade pelas questões estruturais mais profundas, marcas indeléveis impressas pelo protestantismo na sociedade brasileira. Elas existem? Se sim, quais são? E como ocorreram? Se não, o que deu errado? E por quais motivos? A essa questão maior segue-se uma segunda. Na história remota do protestantismo, desde as origens europeias, haveria características e compromissos idiossincráticos desse ramo do cristianismo que servissem de inspiração e de norteadores para que o protestantismo nacional construísse uma proposta eclesial e uma práxis social relevantes?

O primeiro capítulo trata do estabelecimento do protestantismo no Brasil, abrangendo a segunda metade do século XIX. Se não podemos falar propriamente de uma teoria social política, nessa fase, podemos ao menos apontar algumas conquistas políticas que chegam a ser surpreendentes, dada a habilidade de alguns daqueles missionários e também pela convergência de fatores sociais e políticos em curso na sociedade brasileira na segunda metade do século XIX.

O segundo capítulo trata da consolidação do protestantismo brasileiro, analisando a emancipação das primeiras denominações evangélicas já estabelecidas no Brasil. O capítulo também discorre sobre a ética social e política desse período em que setores do evangelismo brasileiro se engajaram em ações concretas, de enorme impacto sobre as igrejas. 
O terceiro capítulo trata da fragmentação do protestantismo brasileiro, percorrendo a trajetória dos evangélicos no pós-64 até os dias atuais. Esse é o período em que a igreja evangélica brasileira, influenciada por ideologias norte-americanas que marcaram a Guerra Fria, alinhou-se com o governo militar e expurgou lideranças progressistas que militavam em algumas denominações e na Confederação Evangélica do Brasil.

Finalmente, o quarto capítulo é uma volta ao passado mais remoto. Uma busca por respostas e por alternativas apresentadas pelo protestantismo nascente e seus desdobramentos ulteriores.

Palavras-chave: Protestantismo brasileiro. Teologia social e política. Teologia pública. 